\title{
Toxoplasma gondii: How an Amazonian parasite became an Inuit health issue
}

\author{
SJ Reiling ${ }^{1}$, BR Dixon ${ }^{1 \star}$
}

\begin{abstract}
Toxoplasma gondii is a protozoan parasite that originated in the Amazon. Felids (mammals in the cat family) are the only definitive hosts. These animals shed large numbers of infectious oocysts into the environment, which can subsequently infect many intermediate hosts, including birds, mammals and, possibly, fish. Human T. gondii seroprevalence is high in some parts of the Canadian Arctic and is associated with adverse health consequences among Inuit population. Since the range of felids does not extend to the Arctic, it is not immediately obvious how this parasite got from the Amazon to the Arctic. The objectives of this overview are to summarize the health impacts of $T$. gondii infection in Inuit in Canada's North and to consider how this infection could have reach them. This article reviews the prevalence of $T$. gondii infection in terrestrial and marine animals in the Canadian Arctic and discusses their potential role in the foodborne transmission of this parasite to humans. Two distribution factors seem plausible. First, felids in more southern habitats may release infectious oocysts into waterways. As these oocysts remain viable for months, they can be transported northward via rivers and ocean currents and could infect Arctic fish and eventually the marine mammals that prey on the fish. Second, migratory terrestrial and marine intermediate hosts may be responsible for carrying $T$. gondii tissue cysts to the Arctic, where they may then pass on the infection to carnivores. The most likely source of $T$. gondii in Inuit is from the consumption of traditionally-prepared country foods including meat and organs from intermediate hosts, which may be consumed raw. With climate change, northward migration of felids may increase the prevalence of $T$. gondii in Arctic wildlife.
\end{abstract}

This work is licensed under a Creative Commons Attribution 4.0 Internationa License.

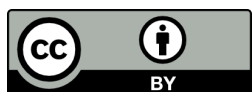

Affiliation

${ }^{1}$ Bureau of Microbial Hazards, Food Directorate, Health Canada, Ottawa, ON

*Correspondence:

brent.dixon@canada.ca
Suggested citation: Reiling SJ, Dixon BR. Toxoplasma gondii: How an Amazonian parasite became an Inuit health issue. Can Commun Dis Rep 2019;45(7/8):183-90. https://doi.org/10.4745/ccdr.v45i78a03

Keywords: toxoplasmosis, marine mammals, fish, climate change, migratory birds

\section{Introduction}

\section{Toxoplasma gondii infection in humans}

Toxoplasma gondii is a protozoan parasite that can infect virtually all birds and mammals (1). Although this parasite originally evolved in the Amazon region of South America (2,3), it now infects an estimated two billion people worldwide, with foci of high prevalence in Latin America, Eastern/Central Europe, the Middle East and South-East Asia and Africa, and lower prevalence in many European countries and both Canada and the United States (4). Humans may become infected via three transmission routes:

- Ingestion of tissue cysts by eating fresh raw meat or organs of an infected intermediate host

- Ingestion of sporulated oocysts, which may persist for months or years in soil or water

- Congenitally, from mother to fetus, if a pregnant woman has acute toxoplasmosis (5)
During the initial infection phase of an intermediate host, including in humans, T. gondii replicates rapidly and spreads throughout the tissues, including the brain (acute toxoplasmosis). In humans, symptoms may be subtle, and otherwise healthy individuals may not notice that they have become infected. Eventually, parasite replication slows down, and the protozoa cluster together in tissue cysts (latent toxoplasmosis). People with latent toxoplasmosis who become immunocompromised may develop reactivated toxoplasmosis, in which the dormant parasites in the tissue cysts will start replicating again. This reactivation can cause severe flu-like symptoms, blurred vision or toxoplasmic encephalitis. Latent toxoplasmosis has also been linked to changes in cell signaling pathways that may lead to neurological disorders including schizophrenia, epilepsy,

Alzheimer's disease and Parkinson's disease (6-11). Furthermore, a positive association has been made between $T$. gondii infection and increased risk-seeking behaviour in humans $(12,13)$. 
Congenital transmission may lead to stillbirth or severe neurological complications.

Socioeconomic factors may have a significant impact on human exposure to this parasite. Factors influencing the seroprevalence in humans include proximity to infected domesticated or wild reservoir hosts, access to clean drinking water, urban versus rural lifestyle, types of food consumed, food preparation (raw vs freezing/cooking/drying) and hygiene (washing hands and rinsing fresh produce) (14).

\section{T. gondii from the Amazon to the Arctic}

Toxoplasma gondii evolved in the Amazon rainforest $(2,3)$. It is very common in the Amazon region and Indigenous populations of the Amazon River basin have the highest known infection rate worldwide: along the upper Rio Negro, T. gondii seroprevalence is greater than $90 \%$ (15). Despite its worldwide distribution, only in the Amazon is T. gondii characterized by a high level of genetic diversity and the presence of many unique genotypes (3). Analysis of the gene flow of unique genotypes indicated that a small number of ancestral lineages gave rise to the existing diversity of T. gondii (2). The primary hypothesis for the worldwide spread of $T$. gondii is that shipping traffic facilitated the travel of domestic cats and infected intermediate hosts to other continents (1). The parasite reproduces in the small intestine of the felid definitive hosts, and millions of oocysts are shed into the environment $(5,14)$. How $T$. gondii spread from the Brazilian rainforest to the Canadian Arctic is not known. In this article, the Arctic boundaries are defined as described by the Conservation of Arctic Flora and Fauna (CAFF), which is the biodiversity group of the Arctic Council. The only wild felid that lives in the Canadian North is the Canada lynx, which has a T. gondii seroprevalence of $14 \%(16)$; however, the lynx's range does not extend north of the treeline (the boreal forest or subarctic). In addition, there are few domestic cats in Canadian Arctic communities. Thus, while the presence of infected felids may explain the spread of $T$. gondiii throughout most of North America, it does not explain the parasite's presence in the Arctic; and, despite the scarcity of potentially infected felids, T. gondii is still present in a wide variety of Arctic animals.

To complete the parasite's lifecycle, oocysts that are shed by the felid definitive hosts need to sporulate (Figure 1) and be ingested by intermediate hosts, which are potential prey for felids and which include virtually all warm-blooded animals. Toxoplasma gondii invades the intermediate host's tissues and disseminates throughout the body, including the brain (1). However, intermediate hosts do not produce oocysts; thus, the mechanism (or mechanisms) of the geographical spread of T. gondii, in the absence of a definitive host, is still unknown.

The objective of this review is to highlight the incidence of this parasite in the Canadian Arctic and its impact on Inuit populations, and to consider how this parasite arrived and became endemic in an environment that lacks definitive hosts.
Figure 1: Lifecycle of a Toxoplasma gondii in Canada's North

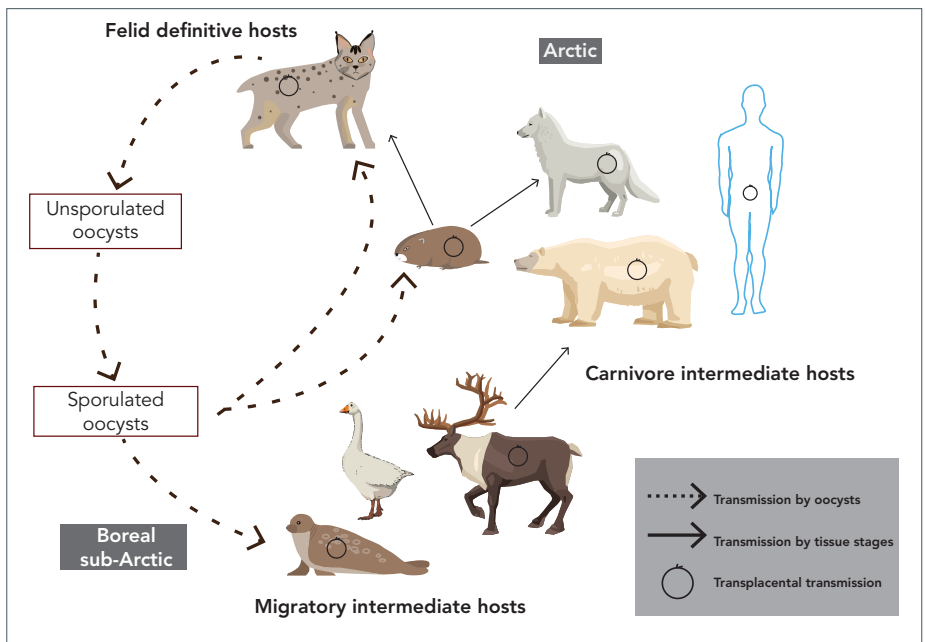

This image was adapted from: Jenkins EJ, Castrodale LJ, de Rosemond SJC, Dixon BR, Elmore SA, Gesy KM, Hoberg EP, Polley L, Schurer JM, Simard M, Thompson RCA. Tradition and Transition: Parasitic Zoonoses of People and Animals in Alaska, Northern Canada, and Greenland. Advances in Parasitology 2013;82:33-204. Reproduced with permission from Elsevier

\section{Toxoplasma gondii in the Arctic}

\section{T. gondii infection in Canadian Inuit}

Toxoplasma gondii infections were first reported in Inuit in the 1980s (17-19). More recent studies showed that T. gondii seroprevalence in Inuit in the Canadian North varies greatly depending upon the region (17). Toxoplasma gondii seroprevalence in adults in three Canadian Inuit regions was reported at $8 \%$ in Nunatsiavut, $28 \%$ in Nunavut and $60 \%$ in Nunavik (20-24). There are not enough data to determine whether T. gondii prevalence in Inuit is stable or has changed over the decades.

Traditionally prepared "country foods" have great cultural significance for Inuit and in general are regarded as safe and nutritious for most people. However, it appears that T. gondii infection is related to the harvest and consumption of "country foods", especially meat and organs, which may be consumed raw $(19,25)$. A correlation between $T$. gondii seroprevalence and different hunting practices and dietary habits has been debated (26-29). In contrast to Inuit communities, neighboring Cree communities, who usually cook their meat, were found to have a T. gondii seroprevalence of only $5 \%$ (29). It has been demonstrated that either thoroughly cooking meat, or freezing meat for several days, kills the pathogens present in the tissue cysts (30).

While toxoplasmosis is often asymptomatic in healthy individuals, pregnant women with acute toxoplasmosis are at risk of transmitting the parasite to the developing fetus. In 1987, an outbreak of toxoplasmosis was reported in pregnant women in Nunavik (19). Infection was associated with skinning of animals and consumption of raw caribou meat (19). 


\section{T. gondii in the absence of definitive hosts}

A study from Svalbard, Norway suggested that the role of oocysts in the transmission of T. gondii to Arctic terrestrial animals has been overemphasized (31). The Svalbard archipelago is free from any wild or domestic cats, which eliminates the spread of infectious T. gondii oocysts into the environment (31). The absence of T. gondii oocysts in Svalbard is supported by findings that non-migratory birds and herbivores were seronegative for T. gondii (31). However, carnivores (foxes) were found to be T. gondii-positive. Thus, migrating birds may have introduced T. gondii to Svalbard, and local carnivores were subsequently infected by eating infected prey. Thus, it is possible for T. gondii to be transmitted from one intermediate host to another (e.g. bird to carnivore) without the need of sexual reproduction of the parasite in a felid definitive host. This transmission cycle between multiple intermediate hosts may explain the prevalence of T. gondii in the Arctic, including the Canadian Arctic, especially in non-felid carnivores. This hypothesis is supported by findings that all tested migratory birds and local carnivores in Svalbard were T. gondii-positive (31).

\section{Canadian Arctic terrestrial animals}

Regardless of the source of infection (environmental oocysts vs tissue cysts from infected prey), numerous mammals and birds in Canada's North have been reported to have tested positive for T. gondii (Table 1). Birds worldwide have been shown to be susceptible to T. gondii infection (31) and in Canada, migratory birds, such as geese, overwinter in areas where felids are common and where infectious $T$. gondii oocysts are likely to be found in high numbers in the environment (32-34). Toxoplasma gondii has been detected in the three tested geese species, with the highest prevalence reported in Ross's geese (34.5\%) and the lowest in Canada geese (5.8\%). Of the ptarmigan species tested, only one rock ptarmigan was found to be T. gondii-positive, possibly due to low exposure to oocysts in their arctic, subarctic and alpine tundra habitats.

Canadian Arctic rodents and lagomorphs showed no prevalence for T. gondii. Nearctic brown lemmings were negative, as were Arctic hares and snowshoe hares (Table 1). The only route of T. gondii transmission for non-migratory herbivores would be via ingestion of soil, plants or water contaminated with infectious oocysts. The absence of T. gondii prevalence in rodents and lagomorphs in the Canadian Arctic support the hypothesis that non-migratory Arctic herbivores have little to no exposure to infectious T. gondii oocysts (31).

The T. gondii exposure of ungulates varied between species. Caribou had a T. gondii prevalence of $11.3 \%$, while the subspecies barren-ground caribou had a prevalence of $36.8 \%$. It is unclear why barren-ground caribou were found to have such a high T. gondii prevalence. Muskox had a T. gondii prevalence of only $4.6 \%$ (Table 1 ).
Table 1: Birds and terrestrial mammals that have been tested for Toxoplasma gondii in the Canadian Arctic ${ }^{a}$

\begin{tabular}{|c|c|c|c|c|}
\hline $\begin{array}{l}\text { Common } \\
\text { name } \\
\text { (References) }\end{array}$ & Latin name & $\begin{array}{l}\text { Number } \\
\text { tested }\end{array}$ & $\begin{array}{l}\text { Number } \\
\text { positive }\end{array}$ & $\begin{array}{l}\text { Percent } \\
\text { positive }\end{array}$ \\
\hline \multicolumn{5}{|l|}{ Birds } \\
\hline $\begin{array}{l}\text { Rock ptarmigan } \\
\text { (35) }\end{array}$ & Lagopus muta & 25 & 1 & $4.0 \%$ \\
\hline $\begin{array}{l}\text { Willow } \\
\text { ptarmigan (35) }\end{array}$ & $\begin{array}{l}\text { Lagopus } \\
\text { lagopus }\end{array}$ & 24 & 0 & $0.0 \%$ \\
\hline $\begin{array}{l}\text { Ross's goose } \\
(36,37)\end{array}$ & Chen rossii & 357 & 123 & $34.5 \%$ \\
\hline $\begin{array}{l}\text { Lesser snow } \\
\text { goose }(36,37)\end{array}$ & $\begin{array}{l}\text { Chen } \\
\text { caerulescens }\end{array}$ & 354 & 110 & $31.1 \%$ \\
\hline $\begin{array}{l}\text { Canada goose } \\
(35,38)\end{array}$ & $\begin{array}{l}\text { Branta } \\
\text { canadensis }\end{array}$ & 240 & 14 & $5.8 \%$ \\
\hline \multicolumn{5}{|l|}{ Mammals } \\
\hline \multicolumn{5}{|l|}{ Rodents } \\
\hline $\begin{array}{l}\text { Nearctic brown } \\
\text { lemming (37) }\end{array}$ & $\begin{array}{l}\text { Lemmus } \\
\text { trimucronatus }\end{array}$ & 84 & 0 & $0.0 \%$ \\
\hline \multicolumn{5}{|l|}{ Lagomorphs } \\
\hline $\begin{array}{l}\text { Snowshoe } \\
\text { hare (35) }\end{array}$ & $\begin{array}{l}\text { Lepus } \\
\text { americanus }\end{array}$ & 8 & 0 & $0.0 \%$ \\
\hline Arctic hare (35) & Lepus arcticus & 2 & 0 & $0.0 \%$ \\
\hline \multicolumn{5}{|l|}{ Ungulates } \\
\hline $\begin{array}{l}\text { Barren-ground } \\
\text { caribou (39) }\end{array}$ & $\begin{array}{l}\text { Rangifer } \\
\text { tarandus } \\
\text { groenlandicus }\end{array}$ & 117 & 43 & $36.8 \%$ \\
\hline Caribou (35) & $\begin{array}{l}\text { Rangifer } \\
\text { tarandus }\end{array}$ & 97 & 11 & $11.3 \%$ \\
\hline Muskox $(35,40)$ & $\begin{array}{l}\text { Ovibus } \\
\text { moschatus }\end{array}$ & 348 & 16 & $4.6 \%$ \\
\hline \multicolumn{5}{|l|}{ Carnivores } \\
\hline Arctic fox (41) & $\begin{array}{l}\text { Vulpes } \\
\text { lagopus }\end{array}$ & 39 & 17 & $43.6 \%$ \\
\hline $\begin{array}{l}\text { Canada lynx } \\
(16,35)\end{array}$ & $\begin{array}{l}\text { Lynx } \\
\text { canadensis }\end{array}$ & 173 & 44 & $25.4 \%$ \\
\hline Wolverine (42) & Gulo gulo & 41 & 17 & $41.5 \%$ \\
\hline Grey wolf (35) & Canis lupus & 37 & 7 & $18.9 \%$ \\
\hline $\begin{array}{l}\text { Black bear } \\
(35,43)\end{array}$ & $\begin{array}{l}\text { Ursus } \\
\text { americanus }\end{array}$ & 43 & 16 & $37.2 \%$ \\
\hline
\end{tabular}

The prevalence of T. gondii in carnivores was high in all species tested, as is to be expected even if the parasite's prevalence in their prey is relatively low. In Canada, T. gondii prevalence was found to be $43.6 \%$ in Arctic foxes, $25.4 \%$ in Canada lynxes, $41.5 \%$ in wolverines, $18.9 \%$ in grey wolves and $37.2 \%$ in black bears (Table 1).

\section{Canadian Arctic marine mammals}

Most pinnipeds in the Canadian Arctic were positive for T. gondii, including harbour seals (16.4\%), ringed seals (10.7\%), bearded seals $(10.0 \%)$, hooded seals (1.7\%) and walrus (14.7\%) (Table 2 ). 
Toxoplasma gondii was not detected in harp seals and more research may be required to determine if different feeding habits protect them from exposure to infected prey.

Table 2: Marine mammals that have been tested for Toxoplasma gondii in the Canadian Arctic ${ }^{a, b}$

\begin{tabular}{|c|c|c|c|c|}
\hline $\begin{array}{c}\text { Common } \\
\text { name } \\
\text { (References) }\end{array}$ & Latin name & $\begin{array}{l}\text { Number } \\
\text { tested }\end{array}$ & $\begin{array}{l}\text { Number } \\
\text { positive }\end{array}$ & $\begin{array}{l}\text { Percent } \\
\text { positive }\end{array}$ \\
\hline \multicolumn{5}{|l|}{ Pinnipeds } \\
\hline $\begin{array}{l}\text { Harbour } \\
\text { seal (26) }\end{array}$ & Phoca vitulina & 311 & 51 & $16.4 \%$ \\
\hline $\begin{array}{l}\text { Ringed seal } \\
(26,35)\end{array}$ & Phoca hispida & 896 & 96 & $10.7 \%$ \\
\hline $\begin{array}{l}\text { Harp seal } \\
(35,44)\end{array}$ & $\begin{array}{l}\text { Phoca } \\
\text { groenlandica }\end{array}$ & 113 & 0 & $0.0 \%$ \\
\hline $\begin{array}{l}\text { Bearded } \\
\text { seal (26) }\end{array}$ & $\begin{array}{l}\text { Erignathus } \\
\text { barbatus }\end{array}$ & 20 & 2 & $10.0 \%$ \\
\hline $\begin{array}{l}\text { Hooded } \\
\text { seal (44) }\end{array}$ & $\begin{array}{l}\text { Cystophora } \\
\text { cristata }\end{array}$ & 60 & 1 & $1.7 \%$ \\
\hline Walrus (35) & $\begin{array}{l}\text { Odobenus } \\
\text { rosmarus }\end{array}$ & 34 & 5 & $14.7 \%$ \\
\hline \multicolumn{5}{|l|}{ Bears } \\
\hline $\begin{array}{l}\text { Polar Bear } \\
(35,44-47)\end{array}$ & Ursus maritimus & 599 & 67 & $11.2 \%$ \\
\hline \multicolumn{5}{|l|}{ Cetaceans } \\
\hline $\begin{array}{l}\text { Beluga } \\
(35,48)\end{array}$ & $\begin{array}{l}\text { Delphinapterus } \\
\text { leucas }\end{array}$ & 69 & 13 & $18.8 \%$ \\
\hline $\begin{array}{l}\text { Bowhead } \\
\text { whale (35) }\end{array}$ & $\begin{array}{l}\text { Balaena } \\
\text { mysticetus }\end{array}$ & 2 & 1 & $50.0 \%$ \\
\hline
\end{tabular}

Polar bears are the only ursines that are considered to be marine mammals because of their dependency on the ocean for food and habitat. Toxoplasma gondii has been detected in polar bears on the Canadian mainland and the Beaufort Sea, with an overall prevalence of $11.2 \%$.

Two Arctic cetacean species have been tested for T. gondii: belugas and bowhead whales (Table 2). Toxoplasma gondii prevalence in belugas in the western Canadian Arctic was found to be $18.8 \%$ (Table 2). Of the two bowhead whales tested, one animal was T. gondii. gondii-positive (35).

\section{T.gondii in Arctic waters}

Toxoplasma gondii DNA has been detected in up to $77 \%$ of samples of treated and untreated surface water and well water worldwide $(49,50)$. In some regions of Canada, increased rainfall has been associated with elevated numbers of $T$. gondii oocysts in surface waters (51). Most of Canada's rivers flow northward; $39 \%$ of Canada's freshwater drains into Hudson Bay and 36\% drains into the Arctic Ocean (52). Oocysts that are washed into seawater are known to remain infective for up to two years and may be disseminated with the ocean currents $(20,53-55)$.

It has been hypothesized that fish could be the missing link between oocysts that end up in the watersheds and infection in marine mammals (56). Toxoplasma gondii oocysts have been found in the alimentary tract of a wild fish (57) and it was shown that oocysts can remain infectious inside a fish's alimentary tract for several hours (58), thereby providing a possible source of infection for apex predators. To date, experimental infection of fish with $T$. gondii tissue cysts has only been reported in zebrafish and only under tightly controlled conditions (57). Toxoplasma gondii has also been reported in a variety of shellfish worldwide (59), and this may provide another source of infection in marine mammals and humans, although this has not yet been documented and confirmed in the Arctic.

To determine if Arctic fish are a potential source of $T$. gondii, we tested muscle tissues of 121 freshwater and euryhaline fish from Nunavik for the presence of T. gondii DNA. Fifteen fish (12.4\%) tested positive for T. gondii using polymerase chain reaction for DNA amplification, followed by Sanger sequencing. Atlantic salmon and Arctic char had a T. gondii prevalence of $26.7 \%$ and $12.0 \%$, respectively. Other fish species that tested positive for T. gondii DNA were lake trout (2.9\%) and brook trout (16.7\%). Toxoplasma gondii was detected in one sculpin $(n=1)$ but it was not found in pike or lake whitefish, possibly due to low sample size ( $\mathrm{n}=2$ and 6, respectively) (Reiling SJ, Boone $R$, Merks H, Dixon BR. Unpublished data, 2018). While these are preliminary findings, more fish from the Canadian Arctic are currently being analyzed in our laboratory for the presence of T. gondii.

\section{Discussion}

There are a number of mechanisms by which $T$. gondii may have been introduced into the Canadian Arctic. Toxoplasma gondii may have been introduced via migratory birds and mammals that became infected by ingestion of oocysts (which may persist in soil and water in geographical regions where felids are present), or infected prey, in their southern habitats and carried the infection with them to the North. The parasite could then be transmitted from one intermediate host to another in the Arctic, even in the absence of definitive hosts. In addition, predators, such as Arctic foxes, wolverines and grey wolves, showed high $T$. gondii prevalence, suggesting that carnivory may also be an important route of transmission in the Arctic. Oocysts shed by felids in the south and transported northwards through waterways may be another source of infection in aquatic animals in the Arctic. Until recently, fish had not been known as a potential source for T. gondii infection. However, our preliminary findings suggest that T. gondii may be present in fish in the Canadian Arctic and could be another source of infection in humans and fish-eating mammals. 
Environmental factors that increase T. gondii prevalence in animals that are hunted by Inuit for subsistence may pose a growing health threat to Inuit in the Arctic regions of Canada. More research is needed to determine how environmental and socioeconomic changes influence T. gondii prevalence in animals and humans in the Canadian Arctic.

Climate change and warmer temperatures may promote forest growth in regions that were previously too cold (60-62). The increasing forest cover could expand the habitat of wild felids, thereby augmenting the release of $T$. gondii oocysts into the environment (20). Higher numbers of oocysts combined with warming temperatures may increase the potential for infection of intermediate hosts, including birds and mammals not yet known to be hosts for T. gondii in the Canadian Arctic. This, in turn, may open up new transmission routes to humans who eat traditionally prepared country foods.

\section{Conclusion}

Toxoplasmosis has now spread throughout much of North and South America primarily through felids. Despite the absence of felids, T. gondii has now extended into Canada's Arctic, and has posed a health risk to Inuit, especially in pregnant women and those with weakened immune systems. The most likely source of $T$. gondii infection in Inuit is through infected intermediate hosts and the consumption of traditionally prepared country foods including meat and organs which may be consumed raw. Preventing infection by cooking or thoroughly freezing fish, meat, and organs and a better understanding of ongoing zoonotic transmission patterns will help to address this risk.

\section{Authors' statement}

SJR collected and analyzed the data. SJR and BRD wrote, proofread and approved the manuscript.

\section{Conflict of interest}

None.

\section{Acknowledgements}

We thank A lqbal and S Lamhoujeb for providing the fish DNA. R Boone and $\mathrm{H}$ Merks have provided excellent technical assistance.

\section{Funding}

This work was supported by the Natural Sciences and Engineering Research Council of Canada (NSERC); Visiting Fellowship in Canadian Government Laboratories Program (SJR); and Health Canada (BRD).

\section{References}

1. Dubey JP. General Biology. In: Toxoplasmosis of Animals and Humans (Second Ed.). Boca Raton, London, New York: Taylor and Francis Group; 2009. pp. 1-20. ISBN 978-1-4200-9237-0 2010. CRC Press.

2. Su C, Khan A, Zhou P, Majumdar D, Ajzenberg D, Dardé ML, Zhu XQ, Ajioka JW, Rosenthal BM, Dubey JP, Sibley LD. Globally diverse Toxoplasma gondii isolates comprise six major clades originating from a small number of distinct ancestral lineages. Proc Natl Acad Sci USA 2012;109(15):5844-9. DOI

3. Shwab EK, Zhu XQ, Majumdar D, Pena HF, Gennari SM, Dubey JP, Su C. Geographical patterns of Toxoplasma gondii genetic diversity revealed by multilocus PCR-RFLP genotyping. Parasitol. 2014;141(4):453-61. DOI

4. Pappas G, Roussos N, Falagas ME. Toxoplasmosis snapshots: global status of Toxoplasma gondii seroprevalence and implications for pregnancy and congenital toxoplasmosis. Int J Parasitol 2009;39(12):1385-94. DOl

5. Jones JL, Dubey JP. Waterborne toxoplasmosis-recent developments. Exp Parasitol 2010;124(1):10-25. DOI

6. Ngô HM, Zhou Y, Lorenzi H, Wang K, Kim TK, Zhou Y, Bissati KE, Mui E, Fraczek L, Rajagopala SV, Roberts CW, Henriquez FL, Montpetit A, Blackwell JM, Jamieson SE, Wheeler K, Begeman IJ, Naranjo-Galvis C, Alliey-Rodriguez N, Davis RG, Soroceanu L, Cobbs C, Steindler DA, Boyer K, Noble AG, Swisher CN, Heydemann PT, Rabiah P, Withers S, Soteropoulos P, Hood L, McLeod R. Toxoplasma modulates signature pathways of human epilepsy, neurodegeneration \& cancer. Sci Rep 2017;7(1):11496. DOI

7. Burgdorf KS, Trabjerg BB, Pedersen MG, Nissen J, Banasik K, Pedersen OB, Sørensen E, Nielsen KR, Larsen MH, Erikstrup C, Bruun-Rasmussen P, Westergaard D, Thørner LW, Hjalgrim H, Paarup HM, Brunak S, Pedersen CB, Torrey EF, Werge T, Mortensen PB, Yolken RH, Ullum $\mathrm{H}$. Large-scale study of Toxoplasma and Cytomegalovirus shows an association between infection and serious psychiatric disorders. Brain Behav Immun. 2019: pii: S0889-1591(18)30699-8. DOI

8. Fabiani S, Pinto B, Bonuccelli U, Bruschi F. Neurobiological studies on the relationship between toxoplasmosis and neuropsychiatric diseases. J Neurol Sci 2015;351(1-2):3-8. Epub 2015 Feb 21. DOI

9. Sugden K, Moffitt TE, Pinto L, Poulton R, Williams BS, Caspi A. Is Toxoplasma gondii infection related to brain and behavior impairments in humans? Evidence from a population-representative birth cohort. PLoS One 2016;11(2):e0148435. DOI

10. Flegr J, Horáček J. Toxoplasmosis, but not borreliosis, is associated with psychiatric disorders and symptoms. Schizophr Res. 2018;197:603-4. DOI

11. Hamdani N, Bengoufa D, Godin O, Doukhan R, Le Guen E, Daban-Huard C, Bennabi M, Delavest M, Lépine JP, Boukouaci W, Laouamri H, Houenou J, Jamain S, Richard JR, Lecorvosier P, Yolken R, Rajagopal K, Leboyer M, Tamouza R. Immunoglobulin sub-class distribution in bipolar disorder and schizophrenia: potential relationship with latent Toxoplasma gondii infection. BMC Psychiatry 2018;18(1):239. $\mathrm{DOI}$ 
12. Sutterland $A L$, Kuin $A$, Kuiper B, van Gool T, Leboyer $M$, Fond $G$, de Haan L. Driving us mad: the association of Toxoplasma gondii with suicide attempts and traffic accidents - a systematic review and meta-analysis [Epub ahead of print]. Psychol Med 2019;49(9):1-16. DOI

13. Samojłowicz D, Twarowska-Małczyńska J, Borowska-Solonynko A, Poniatowski ŁA, Sharma N, Olczak M. Presence of Toxoplasma gondii infection in brain as a potential cause of risky behavior: a report of 102 autopsy cases. Eur J Clin Microbiol Infect Dis 2019;38(2):305-17. Epub 2018 Nov 23. DOI

14. Dubey JP, Frenkel JK. Cyst-induced toxoplasmosis in cats. J Protozool 1972;19(1):155-77. DOI PubMed

15. Bóia MN, Carvalho-Costa FA, Sodré FC, Pinto GM, Amendoeira MR. Seroprevalence of Toxoplasma gondii infection among indian people living in lauareté, Sao Gabriel da Cachoeira, Amazonas, Brazil. Rev Inst Med Trop São Paulo 2008;50(1):17-20. DOI PubMed

16. Simon A, Bigras Poulin M, Rousseau AN, Dubey JP, Ogden $\mathrm{NH}$. Spatiotemporal dynamics of Toxoplasma gondii infection in Canadian lynx (Lynx canadensis) in western Québec, Canada. J Wildl Dis 2013;49(1):39-48. DOI

17. Tanner CE, Staudt M, Adamowski R, Lussier M, Bertrand S, Prichard RK. Seroepidemiological study for five different zoonotic parasites in northern Quebec. Can J Public Health 1987;78(4):262-6. PubMed

18. Curtis MA, Rau ME, Tanner CE, Prichard RK, Faubert GM, Olpinski S, Trudeau C. Parasitic zoonoses in relation to fish and wildlife harvesting by Inuit communities in northern Quebec, Canada. Arctic Med Res 1988;47 Suppl 1:693-6. PubMed

19. McDonald JC, Gyorkos TW, Alberton B, MacLean JD, Richer G, Juranek D. An outbreak of toxoplasmosis in pregnant women in northern Québec. J Infect Dis 1990;161(4):769-74. $\mathrm{DOI}$

20. Jenkins EJ, Castrodale LJ, de Rosemond SJ, Dixon BR, Elmore SA, Gesy KM, Hoberg EP, Polley L, Schurer JM, Simard M, Thompson RC. Tradition and transition: parasitic zoonoses of people and animals in Alaska, northern Canada, and Greenland. Adv Parasitol 2013;82:33-204. DOI

21. Messier $V$, Lévesque $B$, Proulx JF, Rochette $L$, Libman MD, Ward BJ, Serhir B, Couillard M, Ogden NH, Dewailly E, Hubert B, Déry S, Barthe C, Murphy D, Dixon B. Seroprevalence of Toxoplasma gondii among Nunavik Inuit (Canada). Zoonoses Public Health 2009;56(4):188-97. DOI

22. Egeland GM. Inuit Health Survey 2007-2008: Nunavut. Centre for Indigenous Peoples' Nutrition and Environment, 2010. www.mcgill.ca/cine/files/cine/adult_report_nunavut. pdf

23. Egeland GM. Inuit Health Survey 2007-2008: Nunatsiavut. Centre for Indigenous Peoples' Nutrition and Environment, 2010. www.mcgill.ca/cine/files/cine/adult_report_-_ nunatsiavut.pdf
24. Goyette S, Cao Z, Libman M, Ndao M, Ward BJ.

Seroprevalence of parasitic zoonoses and their relationship with social factors among the Canadian Inuit in Arctic regions. Diagn Microbiol Infect Dis 2014;78(4):404-10. DOI

25. Parkinson AJ. The Arctic Human Health Initiative: a legacy of the International Polar Year 2007-2009. Int J Circumpolar Health 2013;72(1):21655. DOI

26. Statistics Canada. Aboriginal Peoples Survey, 2006: Inuit health, education and country food. Ottawa (ON): Stats Can; modified 2013. https://www150.statcan.gc.ca/n1/pub/89637-x/2008004/art/art1-eng.htm

27. Simon A, Chambellant M, Ward BJ, Simard M, Proulx JF, Levesque B, Bisgras-Poulin M, Rousseau AN, Ogden NH. Spatio-temporal variations and age effect on Toxoplasma gondii seroprevalence in seals from the Canadian Arctic. Parasitology 2011;138(11):1362-8. DOI

28. Lévesque $B$, Messier $V$, Bonnier-Viger Y, Couillard M, Côté S, Ward BJ, Libman MD, Gingras S, Dick D, Dewailly E. Seroprevalence of zoonoses in a Cree community (Canada). Diagn Microbiol Infect Dis 2007;59(3):283-6. DOl

29. Campagna $S$, Lévesque $B$, Anassour Laouan-Sidi E, Côté S, Serhir B, Ward BJ, Libman M, Drebot MA, Makowski K, Andonova M, Ndao M, Dewailly E. Seroprevalence of 10 zoonotic infections in 2 Canadian Cree communities. Diagn Microbiol Infect Dis 2011;70(2):191-9. DOI

30. El-Nawawi FA, Tawfik MA, Shaapan RM. Methods for inactivation of Toxoplasma gondii cysts in meat and tissues of experimentally infected sheep. Foodborne Pathog Dis 2008;5(5):687-90. DOI

31. Prestrud KW, Asbakk K, Fuglei E, Mork T, Stien A, Ropstad E, Tryland M, Gabrielsen GW, Lydersen C, Kovacs KM, Loonen MJ, Sagerup K, Oksanen A. Serosurvey for Toxoplasma gondii in arctic foxes and possible sources of infection in the high Arctic of Svalbard. Vet Parasitol 2007;150(1-2):6-12. DOl

32. VanWormer E, Fritz H, Shapiro K, Mazet JA, Conrad PA. Molecules to modeling: toxoplasma gondii oocysts at the human-animal-environment interface. Comp Immunol Microbiol Infect Dis 2013;36(3):217-31. DOI

33. Gotteland C, McFerrin BM, Zhao X, Gilot-Fromont E, Lélu M. Agricultural landscape and spatial distribution of Toxoplasma gondii in rural environment: an agent-based model. Int J Health Geogr 2014;13(1):45. DOI

34. Shwab EK, Saraf $P$, Zhu XQ, Zhou DH, McFerrin BM, Ajzenberg D, Schares G, Hammond-Aryee K, van Helden P, Higgins SA, Gerhold RW, Rosenthal BM, Zhao X, Dubey JP, Su C. Human impact on the diversity and virulence of the ubiquitous zoonotic parasite Toxoplasma gondii. Proc Natl Acad Sci USA 2018;115(29):E6956-63. DOl

35. Al-Adhami BH, Simard M, Hernández-Ortiz A, Boireau C, Gajadhar AA. Development and evaluation of a modified agglutination test for diagnosis of Toxoplasma infection using tachyzoites cultivated in cell culture. Food and Waterborne Parasitology. 2016;2:15-21. DOI 
36. Elmore SA, Huyvaert KP, Bailey LL, Milhous J, Alisauskas RT, Gajadhar AA, Jenkins EJ. Toxoplasma gondii exposure in arctic-nesting geese: A multi-state occupancy framework and comparison of serological assays. Int J Parasitol Parasites Wildl 2014;3(2):147-53. DOI

37. Elmore SA, Samelius G, Fernando C, Alisauskas RT, Jenkins EJ. Evidence for Toxoplasma gondii in migratory vs. nonmigratory herbivores in a terrestrial arctic ecosystem. Can J Zool 2015;93(8):671-5. DOI

38. Verma SK, Calero-Bernal R, Cerqueira-Cézar CK, Kwok OC, Dudley M, Jiang T, Su C, Hill D, Dubey JP. Toxoplasmosis in geese and detection of two new atypical Toxoplasma gondii strains from naturally infected Canada geese (Branta canadensis). Parasitol Res 2016;115(5):1767-72. DOI

39. Kutz SJ, Elkin BT, Panayi D, Dubey JP. Prevalence of Toxoplasma gondii antibodies in barren-ground caribou (Rangifer tarandus groenlandicus) from the Canadian Arctic. J Parasitol 2001;87(2):439-42. DOI

40. Kutz SJ, Elkin B, Gunn A, Dubey JP. Prevalence of Toxoplasma gondii antibodies in muskox (Ovibos moschatus) sera from northern Canada. J Parasitol 2000;86(4):879-82. PubMed

41. Elmore SA, Samelius G, Al-Adhami B, Huyvaert KP, Bailey LL, Alisauskas RT, Gajadhar AA, Jenkins EJ. Estimating Toxoplasma gondii exposure in Arctic foxes (Vulpes lagopus) while navigating the imperfect world of wildlife serology. J Wildl Dis 2016;52(1):47-56. DOI

42. Reichard MV, Torretti L, Garvon JM, Dubey JP. Prevalence of antibodies to Toxoplasma gondii in wolverines from Nunavut, Canada. J Parasitol 2008;94(3):764-5. DOI

43. Philippa JD, Leighton FA, Daoust PY, Nielsen $O$, Pagliarulo M, Schwantje H, Shury T, Van Herwijnen R, Martina BE, Kuiken T, Van de Bildt MW, Osterhaus AD. Antibodies to selected pathogens in free-ranging terrestrial carnivores and marine mammals in Canada. Vet Rec 2004;155(5):135-40. DOI PubMed

44. Measures LN, Dubey JP, Labelle P, Martineau D. Seroprevalence of Toxoplasma gondii in Canadian pinnipeds. J Wildl Dis 2004;40(2):294-300. DOI

45. Atwood TC, Duncan C, Patyk KA, Nol P, Rhyan J, McCollum M, McKinney MA, Ramey AM, Cerqueira-Cézar CK, Kwok OC, Dubey JP, Hennager S. Environmental and behavioral changes may influence the exposure of an Arctic apex predator to pathogens and contaminants. Sci Rep 2017;7(1):13193. DOI

46. Kirk CM, Amstrup S, Swor R, Holcomb D, O'Hara TM. Morbillivirus and Toxoplasma exposure and association with hematological parameters for southern Beaufort Sea polar bears: potential response to infectious agents in a sentinel species. EcoHealth 2010;7(3):321-31. DOl

47. Rah H, Chomel BB, Kasten RW, Hew CH, Farver TB, Follmann EH, Garner GW, Amstrup SC. Serosurvey of selected zoonotic agents in polar bears (Ursus maritimus). Vet Rec 2005;156(1):7-13. DOI
48. Haman KH, Raverty S, Wendte JM, Loseto LL, Ferguson SH, Grigg ME. Infected tissues from hunter harvested beluga (Delphinapterus leucas) in the Western Canadian Arctic. 44th Annual IAAAM Conference; 2013; The Marine Mammal Center Sausalito, California.

49. Bahia-Oliveira L, Gomez-Marin J, Shapiro K. Toxoplasma gondii. In: J.B. Rose and B. Jiménez-Cisneros, editors. Global Water Pathogen Project. Michigan State University, E. Lansing, MI, UNESCO. 2017. http://www.waterpathogens. org/book/toxoplasma-gondii

50. Shapiro K, Conrad PA, Mazet JA, Wallender WW, Miller WA, Largier JL. Effect of estuarine wetland degradation on transport of Toxoplasma gondii surrogates from land to sea. Appl Environ Microbiol 2010 Oct;76(20):6821-8. DOI

51. Bowie WR, King AS, Werker DH, Isaac-Renton JL, Bell A, Eng $\mathrm{SB}$, Marion SA. Outbreak of toxoplasmosis associated with municipal drinking water. The BC Toxoplasma Investigation Team. Lancet 1997 Jul;350(9072):173-7. DOI

52. Statistics Canada. Human activity and the environment. Section 2: Canada's water supply—stocks and flows. Ottawa (ON): Stats Can; 2010. https://www150.statcan.gc.ca/n1/ pub/16-201-x/2010000/part-partie2-eng.htm

53. Lindsay DS, Dubey JP. Long-term survival of Toxoplasma gondii sporulated oocysts in seawater. J Parasitol 2009;95(4):1019-20. DOI

54. Gómez-Marin JE, de-la-Torre A, Angel-Muller E, Rubio J, Arenas J, Osorio E, Nuñez L, Pinzon L, Mendez-Cordoba LC, Bustos A, de-la-Hoz I, Silva P, Beltran M, Chacon L, Marrugo M, Manjarres C, Baquero H, Lora F, Torres E, Zuluaga OE, Estrada M, Moscote L, Silva MT, Rivera R, Molina A, Najera S, Sanabria A, Ramirez ML, Alarcon C, Restrepo N, Falla A, Rodriguez T, Castaño G. First Colombian multicentric newborn screening for congenital toxoplasmosis. PLoS Negl Trop Dis 2011;5(5):e1195. DOI

55. Afonso E, Thulliez P, Gilot-Fromont E. Local meteorological conditions, dynamics of seroconversion to Toxoplasma gondii in cats (Felis catus) and oocyst burden in a rural environment. Epidemiol Infect 2010;138(8):1105-13. DOI

56. Simon A, Poulin MB, Rousseau AN, Ogden NH. Fate and transport of Toxoplasma gondii oocysts in seasonally snow covered watersheds: a conceptual framework from a melting snowpack to the Canadian arctic coasts. Int J Environ Res Public Health 2013;10(3):994-1005. DOI

57. Sanders JL, Zhou Y, Moulton HM, Moulton ZX, McLeod R, Dubey JP, Weiss LM, Kent ML. The zebrafish, Danio rerio, as a model for Toxoplasma gondii: an initial description of infection in fish. J Fish Dis 2015;38(7):675-9. DOI

58. Massie GN, Ware MW, Villegas EN, Black MW. Uptake and transmission of Toxoplasma gondii oocysts by migratory, filter-feeding fish. Vet Parasitol 2010;169(3-4):296-303. DOI

59. Shapiro K, Bahia-Oliveira L, Dixon B, Dumètre A, de Wit LA, VanWormer E, Villena I. Environmental transmission of Toxoplasma gondii: oocysts in water, soil and food. Food and Waterborne Parasitology. 2019;15:e00049. DOI 
60. Lenoir J, Gégout JC, Marquet PA, de Ruffray P, Brisse H. A significant upward shift in plant species optimum elevation during the 20th century. Science 2008;320(5884):1768-71. DOI

61. Feeley KJ, Silman MR, Bush MB, Farfan W, Cabrera KG, Malhi Y, Meir P, Salinas Revilla N, Natividad Raurau Quisiqupanqui M, Saatchi S. Upslope migration of Andean trees. J Biogeogr 2011;38(4):783-91. DOI
62. Fei S, Desprez JM, Potter KM, Jo I, Knott JA, Oswalt CM. Divergence of species responses to climate change. Sci Adv 2017;3(5):e1603055. DOI

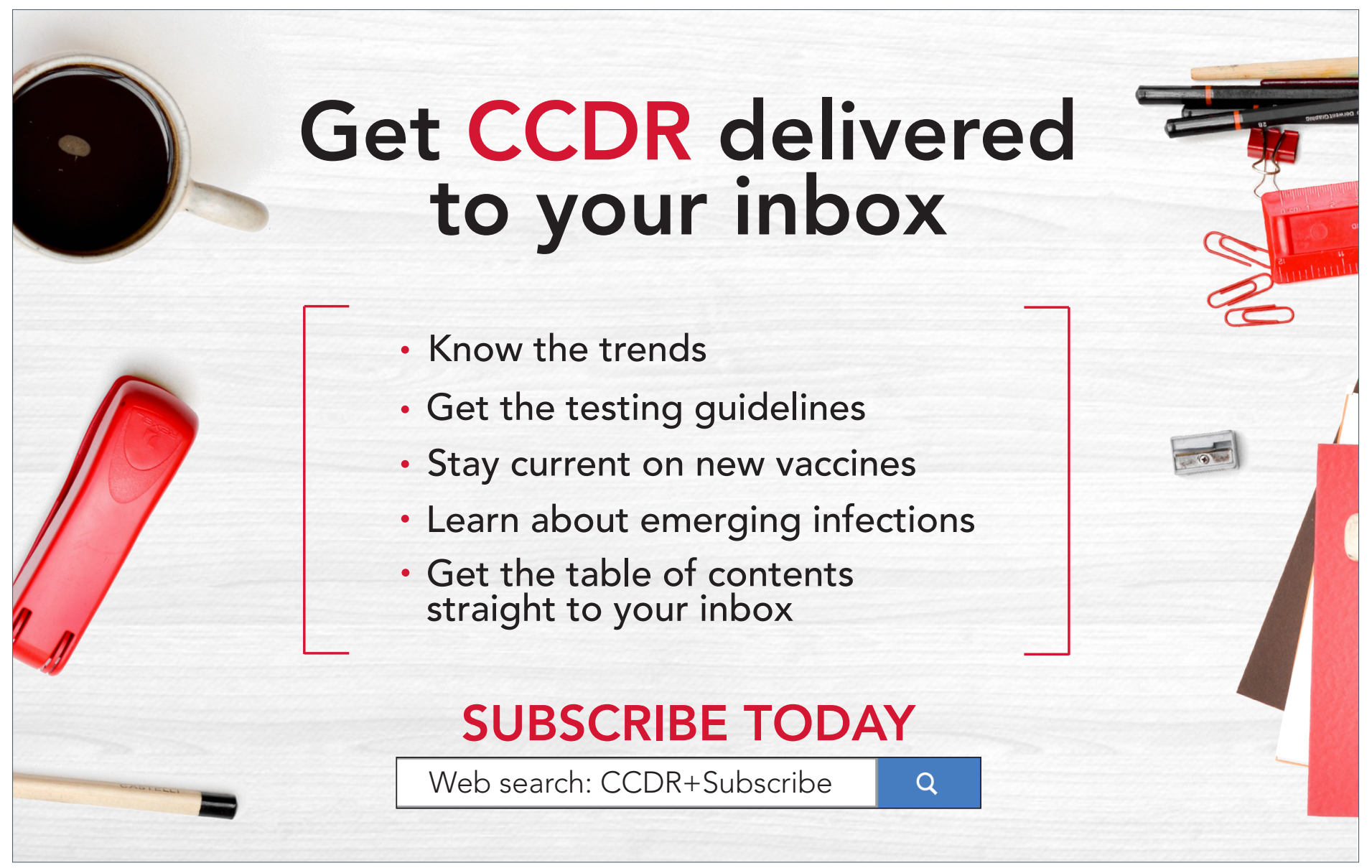

